\title{
Biosorption of aniline blue from aqueous solution using a novel biosorbent Zizyphus oenoplia seeds: Modeling studies
}

\author{
Kumar M. ${ }^{1}$, Elangovan G. ${ }^{2}$, Tamilarasan R. ${ }^{1 *}$, Vijayakumar G. ${ }^{3}$, Mukeshkumar P.C. ${ }^{4}$, \\ Sendhilnathan S. $^{5}$ \\ ${ }^{1}$ Anna University Chennai: University College of Engineering Pattukottai, Department of Chemistry, Rajamadam-614 \\ 701, India \\ ${ }^{2}$ Anna University Chennai: University College of Engineering Pattukottai, Department of Civil Engineering, Rajama- \\ dam-614 701, India \\ ${ }^{3}$ Arignar Anna Government Arts College, Department of chemistry, Musiri-621 211, India \\ ${ }^{4}$ Anna University Chennai: University College of Engineering Pattukottai, Department of Mechanical Engineering, Raja- \\ madam-614 701, India \\ ${ }^{5}$ Anna University Chennai: University College of Engineering Pattukottai, Department of Physics, Rajamadam-614 701, India \\ "Corresponding author: e-mail: rrtamilk@yahoo.co.in
}

\begin{abstract}
This article presents the feasibility for the removal of Aniline Blue dye (AB dye) from aqueous solution using a low cost biosorbent material Zizyphus oenoplia seeds. In this study, a batch mode experiments of the adsorption process were carried out as a function of $\mathrm{pH}$, contact time, concentration of dye, adsorbent dosage and temperature. The experimental data were fitted with Freundlich and Langmuir isotherm equations. The feasibility of the isotherm was evaluated with dimensionless separation factor $\left(\mathrm{R}_{\mathrm{L}}\right)$. The kinetic data of sorption process are evaluated by using pseudo-first order and pseudo-second order equations. The mode of diffusion process was evaluated with intra-particle diffusion model. The thermodynamic parameters like change in enthalpy $\left(\Delta \mathrm{H}^{\circ}\right)$; change in entropy $\left(\Delta \mathrm{S}^{\circ}\right)$ and Gibbs free energy change $\left(\Delta \mathrm{G}^{\circ}\right)$ were calculated using Van't Hoff plot. The biosorbent material was characterized with Fourier Transform Infrared (FTIR) spectroscopy and the morphology was identified with Scanning Electron Microscope (SEM) in before and after adsorption of $\mathrm{AB}$ dye.
\end{abstract}

Keywords: aniline blue, removal, biosorption, Zizyphus oenoplia seed, modeling.

\section{INTRODUCTION}

The environmental pollution is a major problem in developing countries due to the rapid growth of economic, social, educational and industrial development. Most of the countries are extensively using various dyes in their industries like textile, paper, printing, cosmetics, plastics, rubber and dyestuff for coloration of the products. Textile industries consumes very large volumes of water for wet processing such as scouring, bleaching, mercerizing, dyeing, printing and final finishing. The worldwide annual productions of dyes are approximately $7 \times 10^{5}$ tons and $10-15 \%$ of them are discharged directly to the environment from textile industries ${ }^{1}$. The dyes are usually having a synthetic origin and complex aromatic structures. They are stable to light, water, heat and oxidizing agents, therefore it is very difficult to degrade in chemical and biological methods. Some dyes causes allergy, dermatitis, cancer, skin irritation and mutation problems to human beings ${ }^{2}$. Therefore, removal of dyes from effluent becomes most important for the prevention of environmental problems. There are various conventional methods like precipitation ${ }^{3}$, ion exchange $^{4}$, solvent extraction ${ }^{5}$, filtration ${ }^{6}$, electrochemical treatment ${ }^{7}$ are used to remove dyes from the effluent water. But most of the methods have some disadvantages such as consumption of large quantity of chemicals, high cost and incomplete dye removal ${ }^{8}$. These methods are also generating large amount of toxic sludge during the treatment process 9 . Among these adsorption is a most effective method with variety of applications and it is considered as an economical and suitable method for the removal of dyes from wastewater ${ }^{10}$. Many researchers used variety of adsorbent materials for the removal of dyes from aqueous solution. Some researchers studied with earthy clay materials like perlite, zeolite and gypsum $^{11-13}$ for the removal of dyes. Activated carbon is widely used as adsorbents because it has excellent adsorption ability to remove organic compounds but they are having some disadvantages like high operation costs, regeneration and generate toxic sludge or other waste products that requires disposal problems ${ }^{14}$, which limits their usage ${ }^{15}$. Hence, there is a need to explore a locally available and cost effective adsorbent material having high contaminant sorption capacity material ${ }^{16}$. Generally the biosorption processes may reduce the capital costs by $20 \%$, operational costs by $36 \%$ and total treatment costs by $28 \%$ compared with all other conventional methods ${ }^{17}$. There are numerous low cost biosorbents have been studied like Tamarind Fruit Shell ${ }^{18}$, wood sawdust ${ }^{19,}$, fly $\mathrm{ash}^{21}$, tea waste ${ }^{22}$, coconut waste ${ }^{23}$ and peanut hull ${ }^{24}$ for the removal of various dyes from the waste water.

A detailed literature survey shows that Zizyphus oenoplia seeds has not been tried as biosorbent material for the removal of aniline blue dye. The Zizyphus oenoplia is a thorny straggling shrub found throughout the hotter parts of India. The objectives of the present study are to adsorb aniline blue dye from aqueous solution by batch mode studies by using Zizyphus oenoplia seed as a low-cost material. In the batch mode studies, the dynamic behavior of the adsorption was investigated on the effect of dye concentration, temperature, adsorbent dose, $\mathrm{pH}$ and contact time. The Langmuir and Freundlich adsorption isotherms and Lagergren's kinetics equations are used for the evaluation of sorption feasibility process. The thermodynamic parameters were predicted for the determination of the type of interaction between the dye and adsorbent. The surface characterization of the 
biosorbent material was analyzed with FTIR spectroscopy and Scanning Electron Microscope.

\section{MATERIAL AND METHODS}

\section{Preparation and characterization of biosorbent material}

The biosorbent material was collected in the area of Anna University - University College of Engineering Pattukottai premises. The collected seeds are dried without sunlight for 7 days and free from seed shells. Seeds were dried in sunlight for 3 days and it was ground with desired size then washed with distilled water. The material was dried in a hot air oven at $70^{\circ} \mathrm{C}$ at 3 hours for the removal of volatile matters. The powdered biosorbent material was used for the removal of $\mathrm{AB}$ dye. The biosorbent material was characterized by Perkin-Elmer Fourier Transform Infrared (FTIR) spectroscopy and the morphology of the biosorbent material was determined by Scanning Electron Microscope (SEM) before and after adsorption of dye.

\section{Preparation of Dye solution}

Aniline blue (Mol. Formula is $\mathrm{C}_{32} \mathrm{H}_{25} \mathrm{~N}_{3} \mathrm{Na}_{2} \mathrm{O}_{9} \mathrm{~S}_{3}$ and Formula Weight is 737.74) dye was purchased from Loba-chemie, India limited. The stock solution was prepared by adding $1 \mathrm{~g}$ of aniline blue in 1 liter of double distilled water. The biosorption studies were carried out with the desired dilution of the stock solution. The structure of $\mathrm{AB}$ dye is presented in the Figure 1.

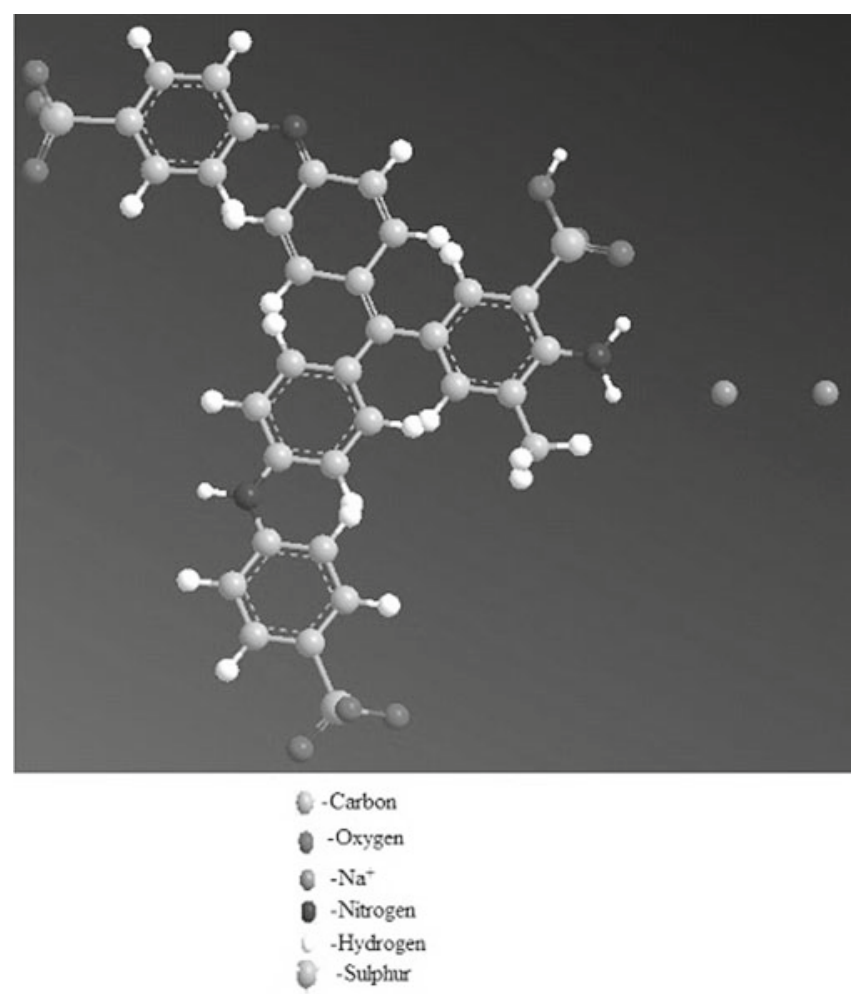

Figure 1. Structure of aniline blue

\section{Biosorption studies}

The biosorption study was carried out by varying the parameters such as $\mathrm{pH}$, concentration of dye, adsorbent dose, agitation time and temperature. The solution $\mathrm{pH}$ was varied in the range of $\mathrm{pH} 3$ to 10 using $0.1 \mathrm{~N} \mathrm{HCl}$ and $0.1 \mathrm{~N} \mathrm{NaOH}$. The concentration of the dye was varied as $10,20,30,40,50,60$ and $70 \mathrm{mg} / \mathrm{L}$. The dose of the adsorbent was varied $0.05 \mathrm{~g}$ to $1 \mathrm{~g}$ with the increment of $0.05 \mathrm{~g}$. The effect temperature for the sorption was determined by varying the temperature from $30,40,50$, 60 to $70^{\circ} \mathrm{C}$. The effect of contact time of the biosorption process was found by varying the time from 10 to 90 minutes with 10 minutes variation.

The percentage removal of dye was calculated using an equation

$\mathrm{R}(\%)=\frac{\mathrm{C}_{0}-\mathrm{C}_{\mathrm{t}}}{\mathrm{C}_{0}} \times 100$

where, $\mathrm{C}_{0}$ and $\mathrm{C}_{\mathrm{t}}$ are the initial concentration and final concentration of dye at time $\mathrm{t}$.

\section{Isotherm studies}

The equilibrium data of the biosorption process was predicted with standard isotherm equations like Freundlich and Langmuir adsorption isotherms. In both equations a linear least-square method examined with various experimental conditions. The amount of sorption at time $\mathrm{t}, \mathrm{q}_{\mathrm{t}}(\mathrm{mg} / \mathrm{g})$ was calculated by the following equation

$\mathrm{q}_{\mathrm{t}}=\frac{\left(\mathrm{C}_{0}-\mathrm{C}_{\mathrm{t}}\right) \mathrm{V}}{\mathrm{M}}$

where, $\mathrm{C}_{0}$ is initial concentration of dye, $\mathrm{C}_{\mathrm{t}}$ is the concentration of dye at a time $t, \mathrm{~V}$ is the volume of dye in $\mathrm{L}$ and $\mathrm{M}$ is weight of activated carbon in $\mathrm{g}$.

\section{Kinetics and thermodynamic studies}

The mode of affinity between dye and biosorbent material was identified using the Lagergren's kinetic equations like pseudo-first order and pseudo-second order equations. The type of diffusion of dye molecule through biosorbent material was found out with intraparticle diffusion model equation. The feasibility of the sorption process was evaluated from the thermodynamic parameters such as change in enthalpy $\left(\Delta \mathrm{H}^{\circ}\right)$, change in entropy $\left(\Delta S^{\circ}\right)$ and change in Gibbs free energy $\left(\Delta G^{\circ}\right)$ using Van't Hoff plot.

\section{RESULTS AND DISCUSSION}

\section{Characterization of Zizyphus oenoplia seeds}

The Zizyphus oenoplia seed was characterized with FTIR spectroscopy and the spectrum was presented in Figure $2 \mathrm{a}$ and $2 \mathrm{~b}$. The Figure $2 \mathrm{a}$ shows various peaks in the position of $3400 \mathrm{~cm}^{-1}, 2926 \mathrm{~cm}^{-1}, 1648 \mathrm{~cm}^{-1}, 1534$ $\mathrm{cm}^{-1}, 1248 \mathrm{~cm}^{-1}, 1046 \mathrm{~cm}^{-1}$ and $611 \mathrm{~cm}^{-1}$. The strong and broad peak at $3400 \mathrm{~cm}^{-1}$ indicated that there is a presence of $\mathrm{OH}$ group. The medium resolution peak at $2926 \mathrm{~cm}^{-1}$ has shown the presence $\mathrm{CH}$ or $\mathrm{CH}_{2}$ interaction of methyl or methylene group present in it. There is a presence of strong and weak band at $1648 \mathrm{~cm}^{-1}$ and $1534 \mathrm{~cm}^{-1}$ reveals that the $\mathrm{C}=\mathrm{O}$ stretching vibration of carboxylate ion. The peaks at $1248 \mathrm{~cm}^{-1}$ (weak band), (strong band) $1046 \mathrm{~cm}^{-1}$ and (broad band) $611 \mathrm{~cm}^{-1}$ positions represent the presence of $\mathrm{C}-\mathrm{O}$ stretching, $\mathrm{C}-\mathrm{O}-\mathrm{C}$ stretching and aromatic nature of biosorbent material. The dye loaded biosorbent material (Fig. 2b) shows definite difference in the peak positions and the intensity of the band are get altered with some extent and there was reduction in the peak height also seen. These changes in the surface of the adsorbent reveals 


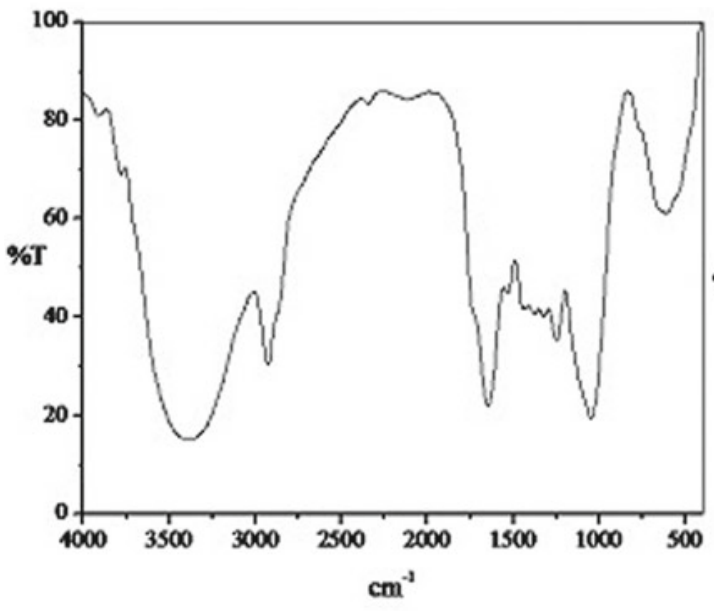

a)

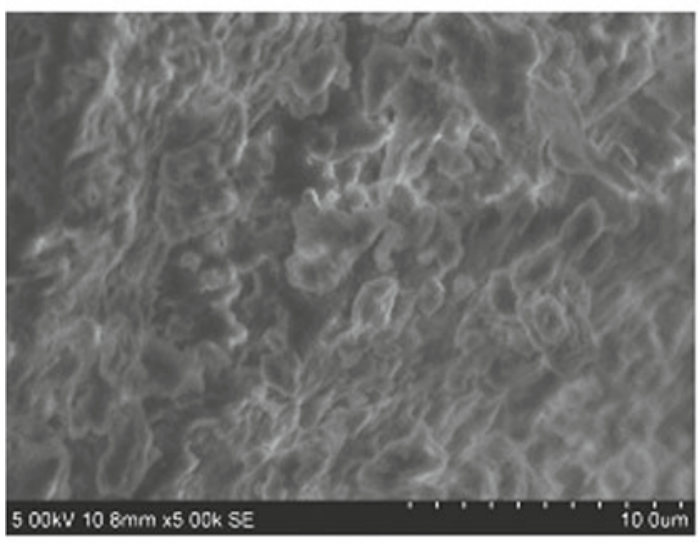

c)

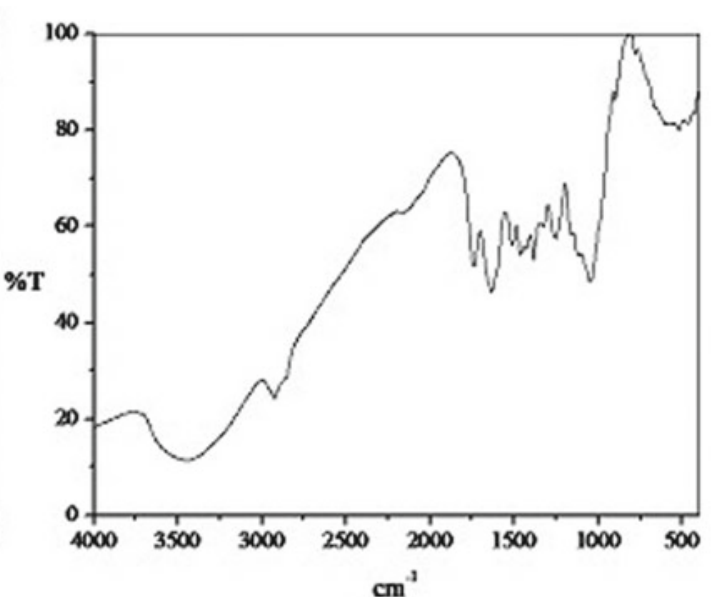

b)

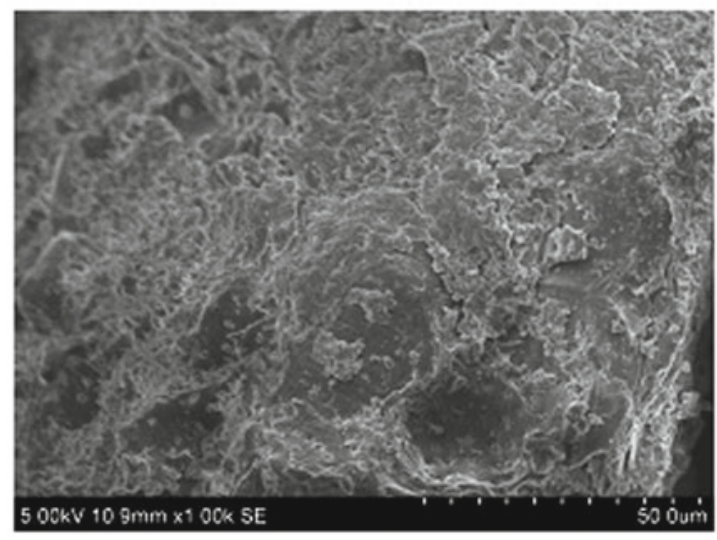

d)

Figure 2. a) FTIR spectrum of biosorbent, b) FTIR spectrum of AB dye loaded biosorbent, c) SEM image of biosorbent, d) SEM image of AB dye loaded biosorbent

that there was a strong sorption process involved during biosoprtion and the interaction between the AB dye and Zizyphus oenoplia seed was predominant. The Scanning Electron Microscopic shows two different Morphological images and that were presented in Figure $2 \mathrm{c}$ and $2 \mathrm{~d}$. The Figure $2 \mathrm{c}$ shows a bright and on the surface. But in the case of Figure 2d, AB dye loaded biosorbent material does not show porous layered structure but it shows that the entire surface covered by the adsorbent.

\section{Effect of pH}

The solution $\mathrm{pH}$ plays a vital role in any sorption process. Depends on $\mathrm{pH}$, the sorption capacity of the biosorbent material was altered with the type of functional groups present on the surface. If the solution $\mathrm{pH}$ attains high value, the biosorbent material is surrounded by the positively charged ions. Thereby negatively charged ions were tending to attract more rapidly rather than positive ions on the surface of the sorbent. On the other hand in low $\mathrm{pH}$ value, the progression of the process was involved in the reverse manner and vice versa. The $\mathrm{pH}$ was found out with the variation of $\mathrm{pH}$ value from 3 to 10. From the various $\mathrm{pH}$ values, the $\mathrm{pH}$ value 5 shows higher percentage removal of $\mathrm{AB}$ dye as compared to other $\mathrm{pH}$ values (Fig. 3).

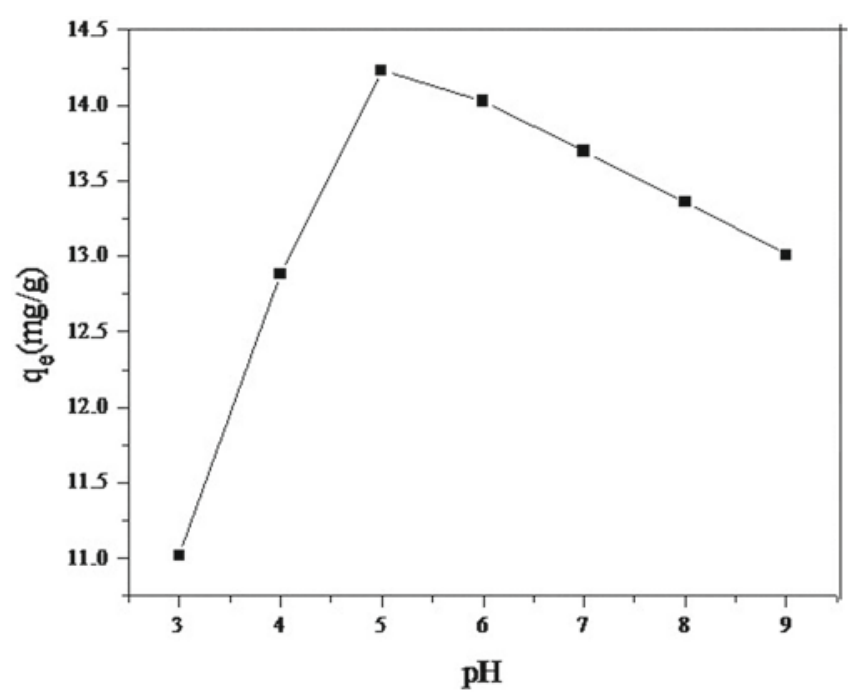

Figure 3. Effect of $\mathrm{pH}$ for the sorption $\mathrm{AB}$ dye

\section{Effect of contact time and dye concentration}

The determination of contact time is essential for any sorption process because it provide the prediction of the equilibrium time. In this sorption process, $100 \mathrm{mg}$ of biosorbent was dispersed in $25 \mathrm{ml}$ of dye solution with various concentrations as 10, 20, 30, 40, 50, 60 and 70 $\mathrm{mg} / \mathrm{L}$ using Erlenmeyer flasks. From the various concentrations of $\mathrm{AB}$ dye $40 \mathrm{mg} / \mathrm{L}$ shows an effective dye removal (96\%), as compared with other concentrations (Fig. 3). For the prediction of equilibrium contact time 
various contact time was evaluated as 10, 20, 30, 40, 50, $60,70,80$ and 90 minutes. From these the effective $A B$ dye removal achieved in 40 minutes (Fig. 4). The other contact times does not provide an expected dye removal as much as 40 minutes. So 40 minutes of contact time and $40 \mathrm{mg} / \mathrm{L}$ of $\mathrm{AB}$ dye concentration are chosen as optimum experimental parameters for the removal of AB dye.

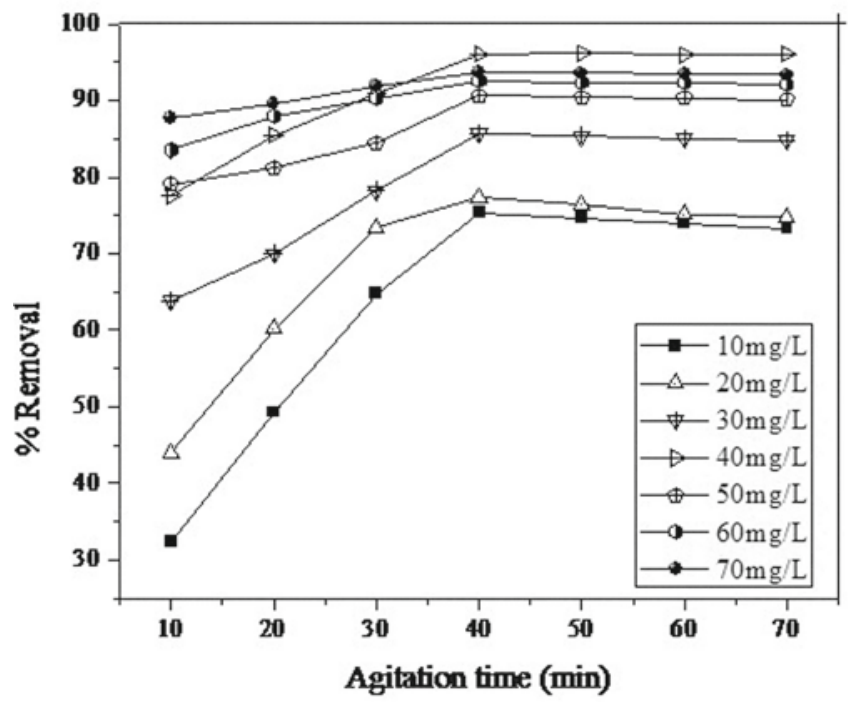

Figure 4. Effect of contact time and dye concentration for the sorption of $\mathrm{AB}$ dye

\section{Effect of biosorbent dose and temperature}

The prediction of an effective biosorbent dose of biosorption process for the removal of $\mathrm{AB}$ dye, various quantities of doses such as $0.05,0.1,0.15,0.2,0.25,0.50$, 0.75 and $1 \mathrm{~g}$ were used. The application of various quantity of biosorbent material, $0.1 \mathrm{~g}$ of the biosorbent dose shows higher percentage removal of $\mathrm{AB}$ dye compared with other doses (Fig. 5). The effect of temperature of biosortion process was predicted in the range of 30 to $70^{\circ} \mathrm{C}$ with the variation of $10^{\circ} \mathrm{C}$. Among various temperatures, $30^{\circ} \mathrm{C}$ (room temperature) shows an effective dye removal i.e $96 \%$ (Fig. 6) other then the higher

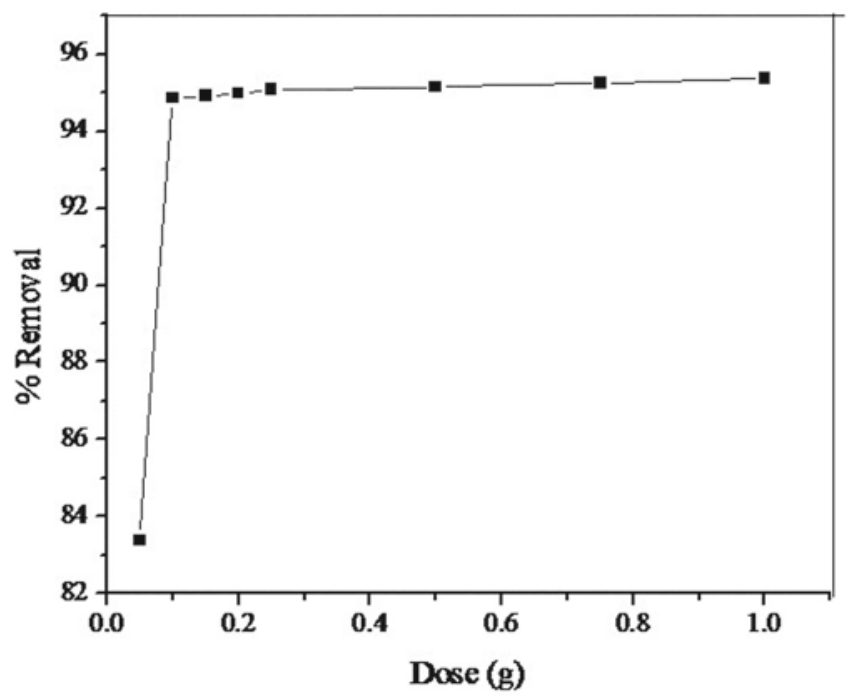

Figure 5. Effect of dose for the sorption of $A B$ dye

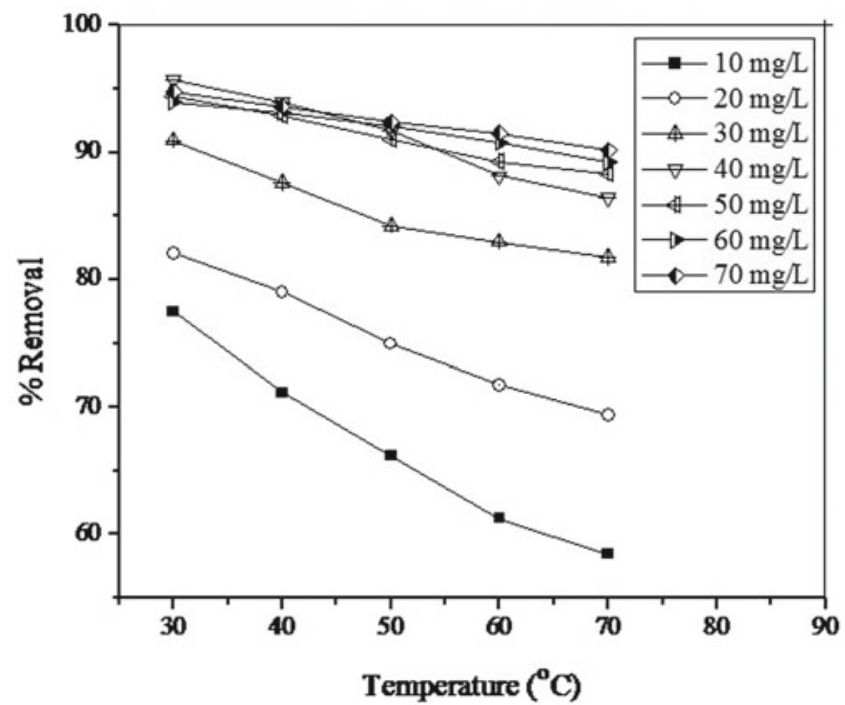

Figure 6. Effect of temperature for the sorptio

temperatures. The increment of temperature does not favor the biosorption process.

\section{Isotherm studies}

The studies on the isotherms of sorption process are able to provide detailed information about the mode of biosorption (i.e) the interaction between the solute and biosorbent. In this study widely used standard isotherm equations like Freundlich and Langmuir isotherm equations were used to predict whether the biosorption involved between the solute and biosorbent material is monolayer or multilayer process. The Langmuir isotherm equation is used for the assumption that the process involved in a monolayer process. Once the solute particle adsorbed on the surface of the biosorbent active site there is no further sorption takes place on the same site ${ }^{25}$.

The mathematical expression of the equation

$\mathrm{q}_{\mathrm{e}}=\frac{\mathrm{q}_{\mathrm{m}} \mathrm{K}_{\mathrm{a}} \mathrm{C}_{\mathrm{e}}}{1+\mathrm{K}_{\mathrm{a}} \mathrm{C}_{\mathrm{e}}}$

The equation (3) can be rearranged in the linear form $\frac{\mathrm{C}_{\mathrm{e}}}{\mathrm{q}_{\mathrm{e}}}=\frac{1}{\mathrm{q}_{\mathrm{m}}} \mathrm{C}_{\mathrm{e}}+\frac{1}{\mathrm{~K}_{\mathrm{a}} \mathrm{q}_{\mathrm{m}}}$

where, $\mathrm{q}_{\mathrm{e}}(\mathrm{mg} / \mathrm{g})$ and $\mathrm{C}_{\mathrm{e}}(\mathrm{mg} / \mathrm{L})$ are the amount of dye adsorbed per unit mass of sorbent and unabsorbed dye concentration in solution, $\mathrm{q}_{\mathrm{m}}$ is the maximum amount of dye adsorbed per unit mass of sorbent at complete monolayer on surface bound, and $\mathrm{K}_{\mathrm{a}}(\mathrm{L} / \mathrm{mg})$ is a constant related to the affinity of the binding sites. These values can be obtained from the linear plot of $\mathrm{C}_{\mathrm{e}} \mathrm{vs} . \mathrm{C}_{\mathrm{e}} / \mathrm{q}_{\mathrm{e}}$. Apart from a common form of the Langmuir isotherm, on rearrangement, various linearized forms were obtained like Langmuir-1, Langmuir-2 and Langmuir-3. The corresponding Langmuir equation constant parameter values are obtained by plotting graph between $1 / \mathrm{q}_{\mathrm{e}}$ vs. $1 / \mathrm{C}_{\mathrm{e}}, \mathrm{q}_{\mathrm{e}}$ vs. $\mathrm{q}_{\mathrm{e}} / \mathrm{C}_{\mathrm{e}}$ and $\mathrm{qe} / \mathrm{C}_{\mathrm{e}}$ vs. $\mathrm{q}_{\mathrm{e}}{ }^{26}$ and predicted values were presented in Table 2. Various forms of Langmuir equation was presented in Table 1.

The Freundlich isotherm equation used for an assumption that the solute-biosorbent interaction involves in a multilayer and non-uniform distribution of the solute particle on the surface of the biosorbent material ${ }^{27}$. 
Table 1. Isotherm equations and their forms

\begin{tabular}{|c|c|c|c|c|}
\hline Isotherms & Non-linear & Linear & Plot & Reference \\
\hline Freundlich & $q_{e}=K_{F} C_{e}^{1 / n F}$ & $\log \left(q_{e}\right)=\log \left(K_{F}\right)+\frac{1}{n F} \log \left(C_{e}\right)$ & $\log \left(q_{e}\right) v s \cdot \log \left(C_{e}\right)$ & 27 \\
\hline Langmuir-1 & \multirow{4}{*}{$q_{\mathrm{e}}=\frac{q_{\mathrm{m}} K_{\mathrm{a}} C_{\mathrm{e}}}{1+K_{\mathrm{a}} C_{\mathrm{e}}}$} & $\frac{C_{e}}{q_{e}}=\frac{1}{q_{m}} C_{e}+\frac{1}{K_{a} q_{m}}$ & $\frac{C_{e}}{q_{e}} v s C_{e}$ & 28 \\
\hline Langmuir-2 & & $\frac{1}{q_{e}}=\left(\frac{1}{K_{a} q_{m}}\right) \frac{1}{C_{e}}+\frac{1}{q_{m}}$ & $\frac{1}{q_{e}} v s \cdot \frac{1}{C_{e}}$ & \\
\hline Langmuir-3 & & $q_{e}=q_{m}-\left(\frac{1}{K_{a}}\right) \frac{q_{e}}{C_{e}}$ & $q v_{e} s \cdot \frac{q_{e}}{C_{e}}$ & \\
\hline Langmuir-4 & & $\frac{q_{e}}{C_{e}}=K_{a} q_{m}-K_{a} q_{e}$ & $\frac{q_{e}}{C_{e}} v s q_{e}$ & \\
\hline
\end{tabular}

The mathematical expression of the equation

$\mathrm{q}_{\mathrm{e}}=\mathrm{K}_{\mathrm{F}} \mathrm{C}_{\mathrm{e}}^{1 / \mathrm{nF}}$

The equation (5) rearranged into the linear form

$\log \left(\mathrm{q}_{\mathrm{e}}\right)=\log \left(\mathrm{K}_{\mathrm{F}}\right)+\frac{1}{\mathrm{nF}} \log \left(\mathrm{C}_{\mathrm{e}}\right)$

where, $\mathrm{K}_{\mathrm{F}}(\mathrm{mg} / \mathrm{g})$ and $\mathrm{n}$ are the Freundlich isotherm constants and indicate the adsorption capacity of the adsorbent and the adsorption affinity for the adsorbate, respectively. The value of $n$ and $K_{F}$ were calculated by plotting a graph between $\log \mathrm{C}_{\mathrm{e}}$ vs. $\log \mathrm{q}_{\mathrm{e}}$ of slope and intercept.

For the prediction of the best fitted isotherm equations, on comparison the Langmuir-1 isotherm shows a higher correlation coefficient $\left(\mathrm{r}^{2}\right)$ value 0.9997 while the other forms shows the correlation coefficient values are 0.9816 , 0.9733 and 0.9822 in Langmuir-2, Langmuir-3 and Langmuir-4 equations respectively (Table 2 ). The Freundlich isotherm shows $\mathrm{r}^{2}$ value 0.9915 . This conclude that the sorption of $\mathrm{AB}$ dye onto Zizyphus oenoplia seed follow Langmuir isotherm and Freundlich isotherm. Thereby the sorption of the $\mathrm{AB}$ dye molecule on the surface of the biosorbent involves both monolayer and multilayer process.

The essential characteristics and feasibility of the isotherm equation is described in terms of dimensionless separation factor $\left(R_{L}\right)$, which is defined as:
$\mathrm{R}_{\mathrm{L}}=\frac{1}{1+\mathrm{bC}_{0}}$

If the $\mathrm{R}_{\mathrm{L}}$ value lies in between 1 and 0 , the adsorption is favorable ${ }^{28}$ if greater than 1 , unfavorable adsorption, while a value attains 1 and 0 , it represents unfavorable and irreversible isotherms, respectively. In our study, the experimental result reveals that the $R_{L}$ values lies between 0 and 1. So, the biosorption of $\mathrm{AB}$ dye onto Zizyphus oenoplia seed was well favored.

\section{Kinetic studies}

The sorption mechanism of adsorption process was determined by various kinetic models. In the present study, the kinetics of the adsorption of $\mathrm{AB}$ dye onto Zizyphus oenoplia seed was determined by using the commonly used kinetic models of Lagergren's pseudo first-order model ${ }^{29,30}$, pseudo second-order model ${ }^{31}$ and the intra-particle diffusion model ${ }^{32}$. The pseudo first-order kinetic equation describes the mode of interaction between the sorbate and sorbent may attributed to the physical force of attraction. The mathematical form of the equation

$\frac{\mathrm{dq}_{\mathrm{t}}}{\mathrm{dt}}=\mathrm{k}_{1}\left(\mathrm{q}_{\mathrm{e}}-\mathrm{q}_{\mathrm{t}}\right)$

where, $\mathrm{q}_{\mathrm{e}}$ is the sorption capacity at equilibrium, $\mathrm{q}_{\mathrm{t}}$ is the sorption capacity at equilibrium at time $\mathrm{t}(\mathrm{mg} / \mathrm{g})$ and

Table 2. Isotherm parameters for the sorption of $A B$ dye

\begin{tabular}{|c|c|c|c|c|c|c|c|c|}
\hline \multirow{2}{*}{ Isotherm } & \multirow{2}{*}{ Parameter } & \multicolumn{7}{|c|}{ Concentration [mg/L] } \\
\hline & & 10 & 20 & 30 & 40 & 50 & 60 & 70 \\
\hline \multirow[b]{2}{*}{ Langmuir-1 } & $q_{m}(m g / g)$ & 0.6164 & 1.6993 & 4.1988 & 7.5936 & 9.0678 & 11.645 & 14.4487 \\
\hline & $\mathrm{K}_{\mathrm{a}}(\mathrm{L} / \mathrm{mg})$ & 0.5850 & 0.3662 & 0.6322 & 2.5403 & 1.0355 & 1.3233 & 1.8555 \\
\hline \multirow{3}{*}{ Langmuir-2 } & $q_{m}(m g / g)$ & 0.8938 & 2.8601 & 4.3168 & 7.9428 & 9.1399 & 11.7855 & 14.5158 \\
\hline & $\mathrm{K}_{\mathrm{a}}(\mathrm{L} / \mathrm{mg})$ & 0.7382 & 0.8422 & 0.6850 & 3.5828 & 1.0833 & 1.4366 & 1.9400 \\
\hline & $r^{2}$ & 0.9413 & 0.9816 & 0.9174 & 0.7864 & 0.9653 & 0.9357 & 0.9677 \\
\hline \multirow[t]{2}{*}{ Langmuir-3 } & $\mathrm{K}_{\mathrm{a}}(\mathrm{L} / \mathrm{mg})$ & 1.6464 & 2.5505 & 1.4970 & 0.6751 & 1.0143 & 0.7220 & 0.5259 \\
\hline & $r^{2}$ & 0.9141 & 0.9592 & 0.9536 & 0.9256 & 0.9707 & 0.9496 & 0.9733 \\
\hline \multirow{3}{*}{ Langmuir-4 } & $q_{m}(m g / g)$ & 0.5107 & 0.7613 & 3.0173 & 11.7444 & 12.3693 & 17.0562 & 28.2345 \\
\hline & $\mathrm{K}_{\mathrm{a}}(\mathrm{L} / \mathrm{mg})$ & 1.5285 & 2.4639 & 1.4390 & 0.6332 & 1.0095 & 0.6917 & 0.5142 \\
\hline & $r^{2}$ & 0.9141 & 0.9592 & 0.9536 & 0.9256 & 0.9822 & 0.9496 & 0.9733 \\
\hline \multirow[t]{3}{*}{ Freundlich } & $1 / n$ & 0.7899 & 0.6053 & 0.3025 & 0.16346 & 0.1632 & 0.1258 & 0.0963 \\
\hline & $\mathrm{K}_{\mathrm{F}}(\mathrm{mg} / \mathrm{g})(\mathrm{L} / \mathrm{mg})$ & 0.5036 & 0.0039 & 0.0031 & 0.0492 & 0.1524 & 0.2033 & 0.2448 \\
\hline & $r^{2}$ & 0.9302 & 0.97031 & 0.9777 & 0.9574 & 0.9903 & 0.9830 & 0.9915 \\
\hline
\end{tabular}


$\mathrm{k}_{1}$ is a rate constant of pseudo-first order sorption (L/ $\min )$. By the rearrangement the of the equation (8) as

$\log \left(\mathrm{q}_{\mathrm{e}}-\mathrm{q}_{\mathrm{t}}\right)=\log \left(\mathrm{q}_{\mathrm{e}}\right)-\frac{\mathrm{k}_{1}}{2.303} \mathrm{t}$

Values of $\mathrm{k}_{1}$ were calculated from the plot of log $\left(\mathrm{q}_{\mathrm{e}}-\mathrm{q}_{\mathrm{t}}\right)$ vs. $\mathrm{t}$. The psudo-first and pseudo-second order equations are presented in the Table 3 .

The pseudo-second order equation states that the interaction between solute and sorbate molecule may be a chemical forces of attraction on the solid surface of the sorbent and the sorbate molecule. The mathematical form of the expression

$\frac{\mathrm{dq}}{\mathrm{dt}}=\mathrm{k}_{2}\left(\mathrm{q}_{\mathrm{e}}-\mathrm{q}_{\mathrm{t}}\right)^{2}$

On rearrangement of equation (9) we get,

$\frac{1}{\left(q_{e}-q_{t}\right)}=\frac{1}{q_{e}}+k_{2} t$

Where, $\mathrm{k}_{2}$ is the pseudo-second order rate constant of sorption. The value of $\mathrm{k}_{2}$ was obtained by plotting a graph between $t$ vs. $t / q_{t}$ of the slope and intercept.

The experimental values were depicted that the pseudo-second order model was the best fitted model compared with the pseudo-first order model. The second-order model shows the $r^{2}$ value 0.9887 whereas the pseudo-first order model shows the $r^{2}$ value 0.8589 (Table 4). Hence, it concluded that the interaction between the solute and sorbent may involve by chemical forces of attraction rather than the physical force for the sorption of $\mathrm{AB}$ dye on Zizyphus oenoplia seed.

The consideration of a sorption process, there are several diffusion process involved such as surface sorption, film diffusion etc... instead of all, the intra-particle diffusion plays a significant role for the determination of adsorption mechanism. The prediction of the rate limiting step of the sorption process, the intra-particle diffusion model was tested ${ }^{33}$

$\mathrm{q}_{\mathrm{t}}=\mathrm{k}_{\mathrm{ip}} \mathrm{t}^{1 / 2}+\mathrm{C}$

where, $\mathrm{k}_{\mathrm{ip}}\left(\mathrm{mg} /\left(\mathrm{g} \cdot \mathrm{min}^{1 / 2}\right)\right)$ is the intra-particle diffusion rate constant. The plot of $\mathrm{q}_{\mathrm{t}} \mathrm{vs}$. $\mathrm{t}^{1 / 2}$ of $\mathrm{AB}$ dye concentration, a multi linearity plot can be observed in Figure 7, indicating that intra-particle diffusion plays a significant role but not only in rate-controlling step. The first and sharper portion is attributed to the boundary layer diffusion of $\mathrm{AB}$ dye molecules. The second portion corresponds to the gradual adsorption stage, where intra-particle diffusion process was rate-limiting step.

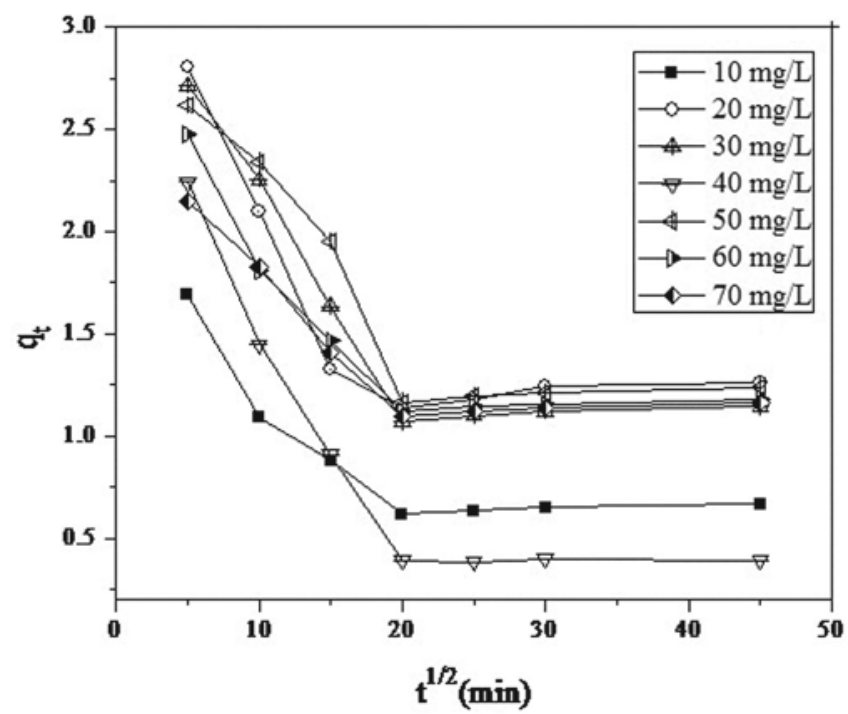

Figure 7. Intraparticle diffusion plot for the sorption of AB dye

Table 3. Pseudo-first order and pseudo-second order kinetic equations and their forms

\begin{tabular}{|l|c|c|c|c|}
\hline \multicolumn{1}{|c|}{ Type } & Non-linear & Linear & Plot & Reference \\
\hline Pseudo first order & $q=q_{e}\left(1-e^{-K_{1} t}\right)$ & $\log \left(q_{e}-q\right)=\log q_{e}-\frac{K_{1} t}{20303}$ & $\log \left(q_{e}-q\right) v s \cdot t$ & 29 \\
\hline Pseudo second order & $q=\frac{K_{2} q_{e}^{2} t}{1+K_{2} q_{e} t}$ & $\frac{t}{q}=\frac{1}{K_{2} q_{e}^{2}}+\frac{1}{q_{e}} t$ & $\frac{t}{q} v s t$ & 30 \\
\hline
\end{tabular}

Table 4. Kinetic parameters for the sorption of $\mathrm{AB}$ dye

\begin{tabular}{|l|c|c|c|c|c|c|c|c|}
\hline \multirow{3}{*}{ Type } & Parameter & \multicolumn{7}{|c|}{$\mathrm{C}_{0}[\mathrm{mg} / \mathrm{L}]$} \\
\cline { 2 - 8 } & $\mathrm{K}_{1}$ & 10 & 20 & 30 & 40 & 50 & 60 & 70 \\
\hline \multirow{3}{*}{$\begin{array}{l}\text { Pseudo-First } \\
\text { order }\end{array}$} & $\mathrm{q}_{\mathrm{e}}$ & 0.0134 & 0.0191 & 0.0114 & 0.0055 & 0.0042 & 0.0024 & 0.0016 \\
\cline { 2 - 9 } & $\mathrm{r}^{2}$ & 0.8240 & 0.8589 & 0.6827 & 0.5058 & 0.5729 & 0.4583 & 0.5004 \\
\hline \multirow{3}{*}{$\begin{array}{l}\text { Pseudo-Second } \\
\text { order }\end{array}$} & $\mathrm{q}_{\mathrm{e}} \mathrm{exp}$ & 1.85 & 3.76 & 6.38 & 9.60 & 11.29 & 13.85 & 16.37 \\
\cline { 2 - 9 } & $\mathrm{K}_{2}$ & 0.1359 & 0.2615 & 0.1233 & 0.1667 & 0.1793 & 0.2711 & 0.1944 \\
\cline { 2 - 9 } & $\mathrm{q}_{\mathrm{e} . \mathrm{cal}}$ & 1.0119 & 3.0311 & 5.0976 & 9.0727 & 10.058 & 12.599 & 15.154 \\
\cline { 2 - 9 } & $\mathrm{r}^{2}$ & 0.9781 & 0.9628 & 0.9744 & 0.9886 & 0.9876 & 0.9810 & 0.9803 \\
\hline
\end{tabular}




\section{Thermodynamic studies}

The thermodynamic parameters were determined for the evaluation of the feasibility of the biosorption process. In this study, three parameters were evaluated such as Gibbs free energy $\left(\Delta \mathrm{G}^{\mathrm{o}}\right)$, change in enthalpy $\left(\Delta \mathrm{H}^{\circ}\right)$ and change in entropy $\left(\Delta \mathrm{S}^{\mathrm{o}}\right)$ from the equations 13 to 15 using Van't Hoff plot (Fig. 8).

$\mathrm{K}_{\mathrm{d}}=\frac{\mathrm{q}_{\mathrm{e}}}{\mathrm{C}_{\mathrm{e}}}$

$\Delta \mathrm{G}^{\mathrm{o}}=-\mathrm{RT} \ln \mathrm{K}_{\mathrm{d}}$

$\ln \mathrm{K}_{\mathrm{d}}=\frac{\Delta \mathrm{S}^{\mathrm{o}}}{\mathrm{R}}-\frac{\Delta \mathrm{H}^{\mathrm{o}}}{\mathrm{RT}}$

The calculated values were presented in the Table 5. From the table the negative value of $\Delta G^{o}$ shows the process was spontaneous and the interaction between the solute and sorbent particle was predominant. The positive value of $\Delta \mathrm{H}^{\circ}$ indicates that the process was endothermic in nature ${ }^{34}$. The positive value of $\Delta S^{o}$ shows that the increased randomness at the solid/solution interface $^{\mathbf{3 5}}$ with some structural changes in the adsorbate and adsorbent and an affinity of the adsorbent toward $\mathrm{AB}$ dye on Zizyphus oenoplia seed.

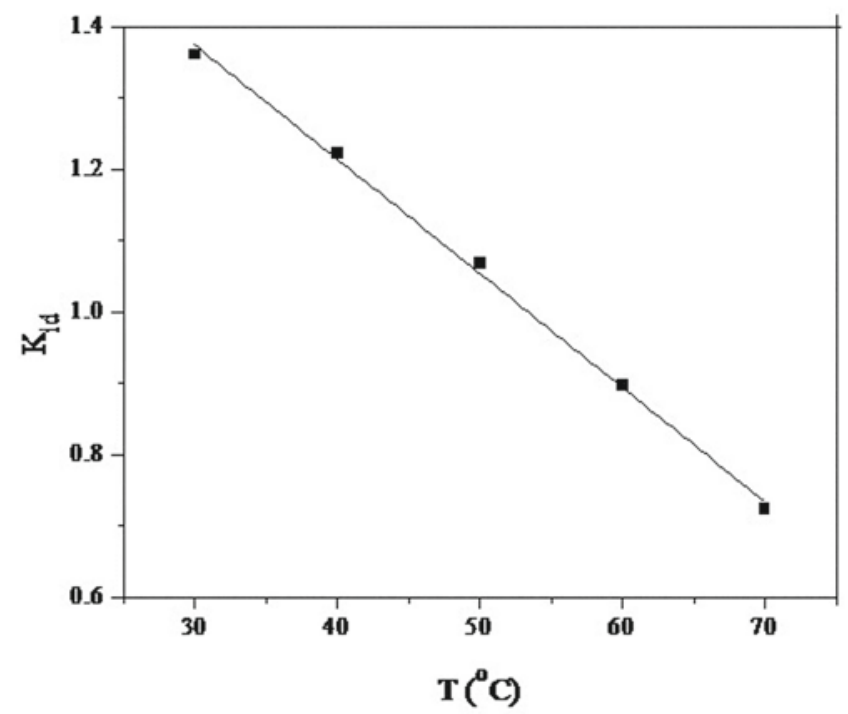

Figure 8. Van't Hoff plot for the sorption of $A B$ dye

Table 5. Thermodynamic parameters for the sorption of AB dye

\begin{tabular}{|l|c|c|c|}
\hline Temperature & $\Delta \mathrm{G}^{0}[\mathrm{KJ} / \mathrm{mol}]$ & $\Delta \mathrm{H}^{0}[\mathrm{KJ} / \mathrm{mol}]$ & $\Delta \mathrm{S}^{0}[\mathrm{~J} / \mathrm{mol} / \mathrm{K}]$ \\
\hline 30 & -0.34 & 0.4 & 15.42 \\
\hline 40 & -0.41 & & \\
\hline 50 & -0.44 & & \\
\hline 60 & -0.45 & & \\
\hline 70 & -0.42 & & \\
\hline
\end{tabular}

\section{CONCLUSION}

The FTIR spectrum of the before and after biosorption shows good resolution, reduction in peak heights and shifted peaks which indicates that a strong attraction between the adsorbent and adsorbate molecules. The SEM images shown a fully covered pores in the after sorption of $\mathrm{AB}$ dye molecule which supports the adsorption process. The feasibility of the sorption of $\mathrm{AB}$ dye onto Zizyphus oenoplia seed was evaluated by varying experimental parameters like dye concentration, temperature, adsorbent dose, $\mathrm{pH}$ and contact time. The prediction of the $\mathrm{pH}$ of the optimum condition, the pH-5 shows well sorbed results compared to the other $\mathrm{pH}$ values. The contact time and dye concentration, 40 minutes of contact time shows an effective removal and $40 \mathrm{mg} / \mathrm{L}$ of the dye shows higher removal percentage of dye. The evaluation for the effect of temperature and adsorbent dose, $30^{\circ} \mathrm{C}$ shows a excellent removal percentage of $\mathrm{AB}$ dye while other temperature does not favor the sorption, the variation of dose of sorbent $0.1 \mathrm{~g}$ of the dose shows an effective removal than the other doses. The determination of the isotherm of the sorption process, Langmuir isotherm shows a well correlated results rather than Freundlich isotherm. This may concluded that the monolayer sorption between the $\mathrm{AB}$ dye and Zizyphus oenoplia seed moreover the evaluation of the Langmuir isotherm using dimension less separation factor $R_{L}$, the values of $R_{L}$ lies between 0 to 1 . This indicated that the sorption of the $A B$ dye and Zizyphus oenoplia seed was favored. The prediction of the kinetic equation, the process follows the pseudo-second order model than the pseudo-first order model. This reveals that the interaction between the $\mathrm{AB}$ dye and Zizyphus oenoplia seed may be of chemical forces of attraction. The negative value of $\Delta \mathrm{G}^{\mathrm{o}}$ shows that process was spontaneous and the interaction between the solute and sorbent particle was predominant. The positive value of $\Delta \mathrm{H}^{\mathrm{o}}$ indicates that the process was endothermic in nature. The positive value of $\Delta \mathrm{S}^{\mathrm{o}}$ shows that the randomness was increases at the solid/solution interfaces. This also support that some of the structural changes in the adsorbate and adsorbent and an affinity of the adsorbent toward AB dye on Zizyphus oenoplia seed. These analytics and experiments are evident that the $\mathrm{AB}$ dye was well adsorbed on the surface of the Zizyphus oenoplia seed.

\section{LITERATURE CITED}

1. Aksu, Z., TatlI, A.I. \& Tunc, O. (2008). A comparative adsorption/biosorption study of Acid Blue 161: Effect of temperature on equilibrium and kinetic parameters, Chem. Eng. J. 142, 23-39. http://dx.doi.org/10.1016/j.cej.2007.11.005

2. Bhatanagar, A. \& Jain, A. (2005). A comparative adsorption study with different industrial wastes as adsorbents for the removal of cationic dyes from water", J. Coll. Inter. Sci., 28, 49-55. http://dx.doi.org/10.1016/j.jcis.2004.08.076

3. Tan, B.H., Teng, T.T., Mohd, A.K. \& Omar, M. (2000). Removal of dyes and industrial dye wastes by magnesium chloride. Water Res. 34, 597-601. http://dx. doi.org/10.1016/ S0043-1354(99)00151-7

4. Liua, C.H., Wua, J.S., Chiua, H.C., Suena, S.Y. \& Chub, K.H. Removal of anionic reactive dyes from water using anion exchange membranes as adsorbers, Water Res. 41(7), 1491, (2007). http://dx.doi.org/10.1016/j.watres.2007.01.023

5. Tuteja, R., Kaushik, N., Kaushik, C.P. \& Sharma, J.K. (2010). Recovery of Reactive (Triazine) Dyes from Textile Effluent by Solvent Extraction Process. Asian J. Chem. 22, 539-545. http://asianjournalofchemistry.co.in/User/ViewFreeArticle. aspx?ArticleID $=22 \_1 \_74$

6. Simonic, M. (2009). Efficiency of ultrafiltration for the pre-treatment of dye-bath effluents. Desalination. 246, 328-334. DOI: 10.1016/j.desal.2009.02.040.

7. Chatzisymeon, E., Xekoukoulotakis, N.P., Coz, A., Kalogerakis, N. \& Mantzavinos, D. (2006). Electrochemical treatment 
of textile dyes and dyehouse effluents Efthalia Chatzisymeon. J. Hazard. Mater 137(2), 998-1007. http://dx.doi.org/10.1016/j. jhaz mat.2006.03.032

8. Ansari, R. \& Mosayebzadeh, Z. (2010). Removal of Basic Dye Methylene Blue from Aqueous Solutions Using Sawdust and Sawdust Coated with Polypyrrole. J. Iranian Chem. Soc. 7(2), 339-350. DOI: 10.1007/BF03246019.

9. Bai, S.R.T. \& Abraham, E. (2001). Biosorption of $\mathrm{Cr}$ (VI) from aqueous solution by rhizopus nigricans. Biores. Tech. 79, 1, 73-81. http://dx.doi.org/10.1016/ S0960-8524(00)00107-3

10. Forgacs, E., Cserhati, T. \& Oros, G. (2004). Removal of synthetic dyes from wastewaters: a review, Environ. Int. 30(7), 953-971. http://dx.doi.org/1 0.1016/j.envint.2004.02.001

11. Irani, M. Amjadi, M. \& Mousavian, M.A. (2011). Comparative study of lead sorption onto natural perlite, dolomite and diatomite, Chem. Eng. J. 178, 317-323. http://dx.doi. org/10.1016/j.cej.2011.10.011

12. Alver, E. \& Metin, A.U. (2012). Anionic dye removal from aqueous solutions using modified zeolite: Adsorption kinetics and isotherm studies, Chem. Eng. J. 15, 59-67. http:// dx.doi.org/10.1016/j.cej.2012.06.038

13. Rauf, M.A., Qadri, S.M., Ashraf, S. \& Al Mansoori, K.M. (2009). Adsorption studies of toluidine Blue from aqueous solutions onto gypsum, Chem. Engg. J. 150, 90-95. http:// dx.doi.org/10.1016/j.cej.2008.12.008

14. Kumar, M. \& Tamilarasan, R. (2013). Kinetics and Equilibrium Studies on the Removal of Victoria Blue Using Prosopis juliflora-Modified Carbon/Zn/Alginate Polymer Composite Beads. J. Chem. Eng. Data. 58, 517-527. http://dx.doi. org/ 10.1021/je3012309

15. Kumar, M., Tamilarasan, R. \& Sivakumar, V. (2013). Adsorption of Victoria blue by carbon/Ba/alginate beads: Kinetics, thermodynamics and isotherm studies. Carbohydrate Poly. 98, 505-513. http://dx.doi.org/10.1016/j.carbpol.2013.05.078

16. Agarwal, G.S., Bhuptawat, H.K. \& Chaudhari, S. (2006). Biosorption of aqueous chromium (VI) by Tamarindus indica seeds. Biores. Tech. 97(7), 949-956. http://dx.doi.org/10.1016/j. biortech.2005.04.030

17. Loukidou, M.X., Zouboulis, A.I., Karapantsios, T.D. \& Matis, K.A. (2004). Equilibrium and Kinetic modeling of chromium(VI) biosorption by Aeromonas caviae. Colloids and Surfaces A: Phys. Eng. Aspec. 242, 93-104. http://dx. doi. org/10.1016/j.colsurfa.2004.03.030

18. Saha, P., Chowdhury, S., Gupta, S., Kumar, I. \& Kumar, R. (2010). Assessment on the Removal of Malachite Green Using Tamarind Fruit Shell as Biosorbent. CLEAN Soil, Air, Water. 38(5-6), 437-445. DOI: 10.1002/clen.200900234.

19. Kapur, M. \& Mondal, M.K. (2013). Mass transfer and related phenomena for $\mathrm{Cr}(\mathrm{VI})$ adsorption from aqueous solutions onto Mangifera indica sawdust. Chem. Eng. J. 218, 138-146. http://dx.doi.org/10.1016/j.cej.2012.12.054

20. Mohanty, K., Das, D. \& Biswas, M.N. (2005). Adsorption of phenol from aqueous solutions using activated carbons prepared from Tectona grandis sawdust by $\mathrm{ZnCl}_{2}$ activation. Chem. Eng. J. 115, 1-2 121-131. http://dx.doi.org/10.1016/j. cej. 2005.09.016

21. Wang, S., Ma, Q. \& Zhu, Z.H. (2008). Characteristics of coal fly ash and adsorption application. Fuel. 87, 3469-3473. http://dx.doi.org/10.1016/j.fuel.2008.05.022

22. Kumar, M. \& Tamilarasan, R. (2013). Modeling of experimental data for the adsorption of methyl orange from aqueous solution using a low cost activated carbon prepared from Prosopis juliflora. Pol. J. Chem. Tech., Vol. 15(1), 29-39. http://www.degruyter.com/view/ j/pjct.2013.15.issue-2/pjct-20130021/pjct-2013-0021.xml? format $=$ INT

23. Sureshkumar, M.V. \& Namasivayam, C. (2008). Adsorption behavior of Direct Red 12B and Rhodamine B from water onto surfactant-modified coconut coir pith. Colloids and Surfaces A: Phys. Eng. Asp. 317 (1-3) 277-283. http://dx. doi. org/10.1016/j.colsurfa.2007.10.026
24. Tanyildizi, M.S. (2011). Modeling of adsorption isotherms and kinetics of reactive dye from aqueous solution by peanut hull. Chem. Eng. J. 168, 1234-1240. http://dx.doi.org/10.1016/j. cej.2011.02.021

25. Langmuir, I. (1918). The Adsorption of Gases on Plane Surfaces of Glass, Mica and Platinum. J. Am. Chem. Soc. 40, 1361-1403. DOI: $10.1021 /$ ja02242a004.

26. Ofomaja, A.E. (2008). Kinetic study and sorption mechanism of methylene blue and methyl violet onto mansonia (Mansonia altissima) wood sawdus, Chem. Eng. J. 143, 85-95. http://dx.doi.org/10.1016/j.cej.2007.12.019

27. Freundlich, H.M.F. (1906). Uber die adsorption in losungen. Zeitschrift fur Physikalische Chemie. 57, 385-470.

28. McKay, G., Blair, H.S. \& Gardener, J.R. (1982). Adsorption of dyes on chitin. I. Equilibrium studies. J. App. Polymer Sci. 27, 3043-3057. DOI: 10.1002/app. 1982.070270827.

29. Lagergren, S. \& Svenska, B.K. (1898). Zur theorie der sogenannten adsorption geloester stoffe. Veternskapsakad Handlingar, 24 1-39. http://www.biodiversity library.org/item/48741

30. Ho, Y.S. \& McKay, G. (1998). Kinetic Models for the Sorption of Dye from Aqueous Solution by Wood. Proc. Saf. Environ. Prot. 76, 83-191. DOI: 10.1205/ 095758298529326.

31. Ho, Y.S. \& McKay, G. (1999). Pseudo-second order model for sorption processes. Process Biochem. 34, 451-465. http:/ dx.doi.org/10.1016/S0032-9592 (98)00112-5

32. Weber, W.J. \& Morris, J.C. (1963). Kinetics of adsorption on carbon from solution. J. Sanitation Eng. Division Am. Soc. Civil Eng. 89, 31-60. http://cedb.asce.org/cgi/ WWWdisplay. cgi?13042

33. Toor, M. \& Jin, B. (2012). Adsorption characteristics, isotherm, kinetics, and diffusion of modified natural bentonite for removing diazo dye. Chem. Eng. J. 187, 79-88. http://dx.doi. org/10.1016/j.cej.2012.01.089

34. Hameed, B.H., Ahmad, A.A. \& Aziz, N. (2007). Isotherms, kinetics and thermodynamics of acid dye adsorption on activated palm ash. Chem. Eng. J. 133, 195-203. http://dx.doi. org/10.1016/j.cej.2007.01.032

35. Kayranli, B. (2011). Adsorption of textile dyes onto iron based waterworks sludge from aqueous solution; isotherm, kinetic and thermodynamic study. Chem. Eng. J. 173, 782-791. http://dx.doi.org/10.1016/j.cej.2011.08.051 